\title{
Issues and Management of Islamic Education in a Global Context
}

\author{
Husna Amin ${ }^{1)}$, Gairah Sinulingga ${ }^{2)}$, Desy ${ }^{3)}$ Erjati Abas ${ }^{4)}$ Sukarno ${ }^{5)}$ \\ 1) UIN Ar-Raniry, Aceh, Indonesia \\ 2.) STIE MBI Depok Jawa Barat, Indonesia \\ 3) Institut Kesehatan Mitra Bunda, Indonesia \\ 4) UIN Raden Intan Lampung, Indonesia \\ 5) STIT Balikpapan, Indonesia \\ e-mail: husnaamin@ar-raniry.ac.id
}

\section{Article Information Abstract}

\section{Keywords:}

Issues, Governance, Education, Islamic Schools, and Literature Review

Kata kunci:

Isu, Tata Kelola,

Pendidikan, Madrasah, dan

Tinjauan Pustaka
The issue of Islamic education management governance in global education is the main objective of this secondary data review. To complete the discussion of this study, we have collected a series of data and literature on several data sources electronically in educational journal publications, book proceedings, and website databases that actively voice Islamic education issues in a global context. We cannot describe the data that we collect directly. We analyze it using various approaches, such as sharp evaluation coding and drawing conclusions that can answer the essence of the problems of this book review. The data we take online is as much as possible to look for the more up-todate ones published in the last ten years. Finally, we can conclude that based on the findings and discussion data, among others, issues relating to the governance of Islamic religious education still leave problems and challenges, including the difficulty of achieving quality education due to issues of teacher resources that are still low in the mastery of technology that is still lacking. Straightforward access to education is still unequal, and issues related to leadership and school leadership in general education and the Islamic religion. We hope that these results will be a meaningful input in developing studies related to issues and governance of education management that will be held in the future.

\footnotetext{
Abstrak

Isu tata kelola manajemen pendidikan Islam dalam pendidikan global menjadi tujuan utama kajian data sekunder ini. Untuk melengkapi pembahasan kajian ini, kami telah mengumpulkan serangkaian data dan literatur dari beberapa sumber data secara elek.tronik dalam publikasi jurnal pendidikan, prosiding buku, dan database website yang aktif menyuarakan isu-isu pendidikan Islam dalam konteks global. Kami tidak dapat menjelaskan data yang kami kumpulkan secara langsung. Kami menganalisisnya dengan berbagai pendekatan, seperti pengkodean evaluasi yang tajam dan penarikan kesimpulan yang dapat menjawab esensi masalah dari ulasan buku ini. Data yang kami ambil secara online adalah sebanyak. mungkin untuk mencari yang lebih up-to-date yang diterbitkan dalam sepuluh tahun terakhir. Akhir kata, dapat kami simpulkan bahwa berdasarkan temuan dan data pembahasan antara lain permasalahan yang berkaitan dengan tata kelola pendidikan agama Islam masih menjisakan permasalahan dan tantangan, termasuk sulitnya pencapaian pendidikan yang berkualitas karena permasalahan sumber daya guru yang masih rendah dalam pendidikan. Penguasaan teknologi yang masih kurang. Akeses langsung terhadap pendidikan masib belum merata, dan isu-isu yang
} 
berkaitan dengan kepemimpinan dan kepemimpinan sekolah dalam pendidikan umum dan agama Islam. Kami berbarap hasil ini dapat menjadi masukan yang berarti dalam mengembangkan kajian-kajian terkait isu dan tata kelola manajemen pendidikan yang akan diselenggarakan di masa mendatang.

\section{INTRODUCTION}

Although there are pretty many studies and publications on the context and content of Islamic education governance in the country and education governance in other Muslim-majority countries (Takayama et al., 2017; Putra et al., 2020; Manullang, Risa, et al., 2021; Manullang, Mardani, et al., 2021) however, researchers believe that there is a minimal discussion about the governance of Islamic education in terms of issues of challenges and implementation of education in the context of global Islamic education (Wiseman, 2010). Thus, as research researchers, they will understand and answer what issues and challenges are still happening in several Muslim and non-Muslim countries (Aown, 2011). These findings will have implications for understanding contemporary educational issues, especially Islamic education, regarding how delivering education is how human resources support education (Scarino et al., 2015). How do different countries understand the situation and condition of education in different parts of the world? We believe that even though they understand Islam, it is possible to implement education; of course, there will be differences and similarities (Tikly \& Barrett, 2011). Thus, these answers will enrich the researcher's understanding and the audio who will read the findings.

It must be admitted that even though the country is a Muslim country with an Islamic education system, in the concept of implementation and evaluation methods, including Islamic learning, here we will find differences and similarities (GEBRIL, 2016; Putra, Liriwati, et al., 2020). Now all of that will become a vehicle for new input materials for developing education in Indonesia. This can be related to several strengths and weaknesses, especially in terms of education and its implementation system, which starts from understanding rather than theory which has implications for the meaning of education (Usman et al., 2017). This is understood to be different, which can hinder each implementation of Islamic studies in each region. This can happen when the implementation is carried out with different systems and techniques in each country (Atkins et al., 2017). So it will be different in understanding the nature and purpose of Islamic teaching. Ideally, this will differ from one region to another, perhaps with studies about the teaching methods and systems applied, whether it is religion as a ritual or intellectual even though they are fellow Muslims. This will undoubtedly be a helpful understanding in developing and providing progress in designing, making policies in the field, especially in Indonesia (Lahmar, 2020).

When viewed from changes in the implementation of education, at least this change in practice is very reasonable. In contrast, the answer is a change in education management because the understanding factor in managing education differs between individual countries and other individuals (van Pinxteren et al., 2021; Hifza \& Aslan, 2020; Hifza et al., 2020). Understanding how the flow of globalization also influences the strategy to increase scholarly outputs in one place, then also influenced by various advances in education technology in every application at the school level (Kuraedah et al., 2018). In particular, technology has provided innovation in a country while still based on traditional guidelines and principles in other countries. Some Muslim countries do not see technology as an innovation. They still work the old way (Bashori et al., 2020). So when asked how the development of Islamic education in the latest scientific studies is 
not necessarily understood correctly. Even though the presence of technology, if it can be appropriately applied, will impact the learning output in a country. The point changes in practice from one country to another against the background of globalization factors, technological developments, and knowledge in one place (St. Amant, 2017). Finally, all of that will affect educational attainment in each country and regional context, which will give a different color from one Islamic country to another (King, 2010; Suroso et al., 2021).

This has become the basis for thinking that education is carried out according to understanding best practice education in a country (Wang, 2007). This provides a new vehicle for how educational implementation activities run practically; education in a country will not be as important as best practices in other countries. This is closely related to the unique understanding of education (Hunter-Johnson et al., 2014). Policies in a country context are often determined by state policies and pragmatic approaches in the education environment locally and globally (Marienko et al., 2020). All of this will provide an understanding of the thinking on the management of education in each country. However, the study's findings suggest that education in practice is end result-oriented with success; this endeavor will allow students to get many learning outcomes. Especially students receiving education will get a lot of skills and knowledge that are very useful in solving life problems (Lugmayr et al., 2014). Educational administrators understand how research results will have a significant impact. The researchers' observations also asked how educational practices in a place had a significant impact on a nation's human resources quality. This will be a new understanding to be practiced in the following country because quality studies in various educational contexts in one place will provide new input to be practiced in other places (GEBRIL, 2016).

Many things can be studied in the context of global education, but this must refer to the practice of understanding the 21 st-century education model, which, among other things, aims to create and produce quality education with good communication skills (Amukowa \& Ayuya, 2013). So this principle emphasizes that every graduate has skills in communication, how practice in one place in an Islamic country is possible in the following Islamic country, and how 21stcentury education is practiced ethically based Islamic values and principles so that it becomes truly effective teaching and has clear goals. This can happen if efforts to improve human resources progress to competition between countries (Scheer et al., 2011). Likewise, leaders can give freedom to each student to learn according to their interests and abilities because the most important thing is how the practice and leadership of the command can provide a positive feedback input on the development of their educational progress (Kay \& Greenhill, 2011). Then how the correct educational practice involves students for decision making. This means that education is not based on top-down but from the bottom up, where the involvement of students and field teachers will color public policy. These models are examples of 21 st-century educational practices that perhaps every country has not been able to apply these 21 st-century practices fully (Sudarmo, 2020; SUDARMO et al., 2021).

However, another education relevant to the individual development of Muslim students in studies of Islamic education is how after the educated person has educational norms such as changes in individual behavior for the better (Nordin \& Surajudeen, 2015). Individual development is also concerned with moral and ethical development, according to Islam. The behavior of educated people compared to those who cannot receive an education will undoubtedly be different. So, here when education is in a place that is unable to develop creativity, then what happens is that problems arise that are increasing. So that hard work does 
not produce the expected scholarly output, and also the standard of living is increasingly unattainable. According to Islamic values and teaching, intentions must determine all processes passed in the wrong heart upbringing (Sahin, 2018). If the education results are not in line with expectations, this is sure to be influenced by an incorrect education implementation system so that studies that raise the issue of declining educational outcomes must be prioritized. Currently, what is happening about Islamic education in a country will become a new issue and input for the following country (Trinova et al., 2020).

Because all recognize that education in any context must be able to change the people, the community, and the implementers of education themselves, this must be something that stimulates economic growth, moral improvement, ethical improvement, and also socio-cultural development in a place (Purwati et al., 2018). This indicates that if education is successful, it will create innovation, give birth to productivity, and give birth to competitive human resources. Education is also a strengthening of history, how history can prove a positive social change in a society, so good educational outcomes must increase political participation, social equality, and the continuity of a healthy life (Safiah et al., 2020; Aslan, 2019). All of that must impact managed education to make significant changes in a community group and an Islamic state (Mawardi \& Supadi, 2018). Regarding Islamic education in a country, this is very important to be discussed in higher education. Educational investments with practical advantages are usually understood as the implementation that will result in positive contributions. This is carried out from how educational leadership in an area will make a positive contribution to improving and improving the learning experience so that it will be a learning outcome that will be rich and with Islamic and global perspective (Mawardi \& Supadi, 2018).

Based on the problems and introduction above, the authors believe that reviewing the findings of Man's previous studies to gain a deep understanding of the knowledge and skills that are important to learn in the context of understanding issues of governance of Islamic education in the global order (Arkoudis et al., 2013). By reviewing the findings of previous studies, will provide a background on why this study is essential to be able to photograph the planning of how the development and improvement of educational issues in a place or a country will become input in efforts to make changes in other countries in the context of Islamic education in the community (Pringle, 2010). Through the field study findings, the author will get revelations in the form of concepts from evaluating critical data about knowledge and specific information from discussing issues of educational practice that occur in a country (National Research Council, 2012).

So with consideration to review the literature related to Islamic education issues and governance in a global context. This story tells about the importance of understanding education issues to understand the existing data better. So that it can be a material for discussion and relevant debate to solve specific topic issues in the world of Islamic education itself, and then later it can be presented as new knowledge in the form of reports on Islamic education studies (Nitecki \& Wasmuth, 2017). So this is a critical salary that is very relevant if anyone wants to develop an understanding of various data and literature related to issues and governance of education management, especially Islam, the results of which will later become new considerations in efforts to solve educational problems from one place to another quickly (Wiseman, 2010). 


\section{METHODS}

In this section, we try to describe some of the procedures and what we are involved in carrying out this study, starting from preparing the problem of searching for analytical data to the final reporting (Pathak et al., 2013). We first conducted this study to understand the issues and governance of Islamic education in various application contexts (de Casterlé et al., 2012). Then we conducted an online search for data on database sources that discussed education issues and predominantly Islamic and general religious education. After the data revenue, we analyzed it by involving several application system applications such as coding the in-depth analysis. After understanding, we can then find answers to this incident based on valid and reliable data (Graue, 2015). The kingdom is entirely dependent on secondary data, and we find online on several complications both domestically and internationally actively discussing educational issues and issues related to the problems still faced by educational practice globally and globally (Christensen et al., 2011). We design this study is a descriptive qualitative form where we explore the data as much as possible to gain an in-depth understanding of management issues and governance to achieve optimal results. In writing this report, we have followed some of the guidelines for the previous studies to follow the procedures and methodologies of education research carried out previously. For the data that we present to be updated, we limit it to data published last year (McMillan \& Schumacher, 2010).

\section{RESULTS AND DISCUSSION}

\section{Critical of best education practice}

In this section, we will describe the results of the data analysis and discussion of this study. So it is repeated that why the importance of education is practiced correctly, this is nothing but best practice; it is essential because it will process how students can be educated and produce highly competent graduates (Mize, 2019). This is not easy to do because it requires a superior best practice which will happen through trial and error. This is all a process towards the desired result (Suripto, 2020). When best practice occurs, the results obtained will also have an effect. The advantages of best practice education in a place or country will impact many things; in terms of improving students' cognitive abilities, students will also give birth to competencies that can answer problems in a country (Kautz \& Heckman, 2014). So when this best practice is implemented, it will undoubtedly bring benefit, not only in the world of work but also in improving the quality of life of each individual because this education not only gives birth to humans who are ready to work, materially but humans who are superior in terms of culture, morals, and ethics. This is one of the relevance between best practices and the goals of Islamic education, which is combined between emotional intelligence, intellectual intelligence, and spiritual intelligence (Huda et al., 2016).

If all the potential of these students has been appropriately achieved, the community or society will get a positive contribution after the community has protected or passed the phase of formation of education based on the principles of Islamic goals (Subotnik et al., 2011). With a good education, all members of society will have an intellectual sensuality when they build their country. So here it is concerned with how quality education opportunities and these opportunities can be obtained equally, there is no difference to serve proper education, there is no social class and also differences between genders, all of which will increase the quality of community resources in a place (Miettinen, 2013). Likewise, every implementation of education must have a concept, a key to the success of education itself. Because superior education 
certainly has challenges (Cummings, 2014). Education must be able to face the life that continues to compete.

Usually, someone who has a pretty good quality education will have an advantage in dealing with life (McGregor et al., 2015). He has the knowledge and skills that will help him get the opportunity to get a job towards a better future. Having various possibilities to be good in his career, good personal mental development, and a good education will undoubtedly play an essential role in the world of work and following the demands of the 21 st century that is happening today (Beck, 2014). Finally, all must believe that an excellent Islamic education will certainly make the lives of Muslims in a country better. This will increase activity at work and give a sense of equality and Islamic solidarity so that there is no difference in the gap between one group in society to another (Stevenson, 2010). In other words, a good education will undoubtedly show the importance of hard work. That is number one and the importance of valuing time and understanding individual development and growth. So the proper education can form a Muslim community that also believes and provides an understanding of respecting the truth, respecting the laws and regulations in which Muslims live (Orchard et al., 2021).

\section{Learning outcome issues}

Recently, Indonesia is said to be carrying out educational reforms, public education, and religious education (Zulfikar, 2010). However, the current actual condition of Islamic education in Indonesia is still stagnating with various challenges and problems, including improving the quality of teacher resources, equitable access to learning, mastery of science and technology, and many problems that hinder efforts to achieve optimal educational outcomes as desired in the national curriculum (Setiawan, 2020) even though the reform agenda was launched approximately 20 years ago when the New Order regime was replaced with reform efforts towards education reform, which has not been maximally achieved, even though significant funds and curriculum innovations continue to be carried out from the expectations of the global community (Harris \& Jones, 2020; Aslan, 2019a; Aslan \& Wahyudin, 2020).

The challenges and content of issues related to education governance in Indonesia are also experienced by many other developing countries, which should have been around 20 years ago when reforms were rolled out (Sukmayadi \& Yahya, 2020). However, the issue of strengthening the education system for teacher resources and the allocation of learning and overall education management is still an exciting issue to study so that later it will get meaningful input after fending off issues that hinder the achievement of educational goals as required by educational success—education in the 21st century (Agus et al., 2020).

\section{Reforming education in the Indonesian context}

On the one hand, there are many criticisms of reforming and re-evaluating education in Indonesia, especially Islamic education, as part of educational issues in a global context (Shah \& Ghazi, 2015). Nevertheless, on the other hand, no solution or approach can solve the problem instantly when starting from the task of educators, namely the readiness of the teacher to educate students and prepare human resources for students to make students think humane intelligently and religiously. So the educational solution provided must refer to the effectiveness of studentcentered education, the extent to which quality can be improved (Al-Samarrai, 2013). In evaluating the score in the form of a score, it cannot be denied that the score issued is very high, but if it looks for the correlation between a high score and the quality of human resources, it is 
still far behind compared to human resources. This developed country has become a chore and a challenge in itself, which has a great relationship with issues of education governance, especially Islamic education in the Islamic country itself (Kolb \& Kolb, 2009).

The teacher problem is a considerable problem wherein a rough understanding there are still many Indonesian teachers and education personnel who are still shackled in their ability to position themselves as lecturers, teachers, and religious educators (Pribudhiana \& Don, 2021). How do they transfer their skills, knowledge, and experience to change efforts to improve the quality of student learning outcomes if they still doubt the profession's ability? Understanding and educational skills are far from expectations (Dewantara, 2020). Another issue that is most prominent in Indonesia is equal distribution of opportunity and the quality of education for students, where it is illustrated that the quality of education in cities with all-inclusive services cannot be compared with the quality of education services in remote areas in the provinces, even though the government has stated that education must be equitable. However, there are obstacles in its implementation in the field that lead to quality, which is still a common issue and challenge (Rumahlatu et al., 2016).

Indeed, the success of education cannot be measured by the ability of teachers to educate, the ability of school management to organize, and the ability of the government to fund education. However, there are many other reasons why educational attainment is still very low (Kusaeri et al., 2018). In addition, the low socioeconomic status of the Indonesian people makes the quality of education and the ability and care of parents deficient (Kartianom \& Retnawati, 2018). With socioeconomic conditions that do not improve, there is not enough support to concentrate parents' minds to give attention and motivation. As a result, their children cannot be actively learning, and low motivation will undoubtedly impact the child's ability to complete their daily tasks (Toi, 2010). Although the concept of an education center must be innovative, efficient, and practical, it must be admitted that it is not easy in practice. Local delivery systems when the understanding of a centralized government system is often not welcomed and applied in the regions (Wajdi \& Aulia, 2019). These obstacles and leadership problems become evident how the government launches superior policies, but when in the field in local schools, it cannot be applied correctly, so that it still adds to problems such as the uneven quality of education services, regulations, and policies between the center and the regions that often overlap (Rosser, 2018). Not to mention the unequal service opportunities for studying in public and private schools. Because of this quality equity problem, the decline of education in Islamic and modern education is a problem (Bunawan et al., 2019).

Referring to the curriculum issue document in Indonesia, it is true that every time the regime changes, the tendency of state officials to review and evaluate until all new curricula are born every five years (Indartono \& Hamidy, 2019). When viewed in terms of educational attainment, there is almost no significant impact. It seems because the curriculum is a product of documentation that cannot move without teachers and leaders, and students to understand and act accordingly. Logically, the curriculum cannot return to the human resources of teachers and students and is also supported by a good family; the achievement of educational goals will be carried out well (Pambudi \& Harjanto, 2020). Judging from the problem of student motivation and creativity, it is clear that Indonesia is the same as other countries, which is still in contention. The low participation of students in learning in this school shows a relationship between parental support, socioeconomic ability to support learning, and student activities. In the end, what 
happened was a drastic decline in the quality and equity of learning, especially in the regions (Putra, Liriwati, et al., 2020; Aslan et al., 2020).

By referring to healthy modern education, this is indeed a perfect thing, but when in practice, not everything contained in modern education documents can be applied, we read and understand the learning to be achieved what is stated in the 21 st-century learning outcomes is not easy to achieve (Lubis, 2018). This is not easy; it takes hard work, requires understanding and educational leadership skills to translate into implementation. The concepts and targets achieved were published internationally after running a modern wedding; there are still many in the area (Lubis, 2018). In Indonesia, which cannot motivate students to learn to move, especially in countries where schools provide Islamic teachings, sometimes confusion about modern understandings related to religion occurs asynchronously, resulting in significant stagnation in efforts to achieve educational goals. In line with international expectations and the expectations of the Islamic world as a whole (Abidah et al., 2020).

\section{CONCLUSION}

Arriving at this conclusion section, we summarize the study's findings to understand Islamic management issues and governance in various contexts. We believe in exposing the evidence of field findings from various data sources on educational publications and related issues in the international world. We will summarize the points that we got from the land, among others; in the results section, we describe the importance of best practices in education to realize the dream of getting quality education results.

Other points that we present include issues related to the achievement of student learning outcomes. In this context, we mention that after Indonesia entered the reformation era, Indonesian education, both public-private and religious schools, was also equal in access to education, issues of mastering technology, and other issues that had affected efforts to achieve the expected educational outcomes as stated in the ideals of development. Others, including since the reformation, many parties have tried to give criticism and input so that education can be re-evaluated, but what happened was that the problem was so big the challenge was so heavy that until now, the problem has not been able be solved, it is indicated by the quality of Indonesian education as far as indicated by the results of international tests for students, which occupies the closing ranking above. It is hoped that the findings of this study will have answered some of the questions of this study by exposing the data that we have examined from various sources. We realize that this report is still far from expectations, but we hope that in the future, we can improve these findings by revising back in the test material section to make the expected improvement results. 


\section{REFERENCES}

Abidah, A., Hidaayatullaah, H. N., Simamora, R. M., Fehabutar, D., \& Mutakinati, L. (2020). The impact of covid-19 to indonesian education and its relation to the philosophy of "merdeka belajar". Studies in Philosophy of Science and Education, 1(1), 38-49.

Agus, C., Cahyanti, P. A. B., Widodo, B., Yulia, Y., \& Rochmiyati, S. (2020). Cultural-based education of Tamansiswa as a locomotive of Indonesian education system. In Universities as Living Labs for Sustainable Development (pp. 471-486). Springer.

Al-Samarrai, S. (2013). Local governance and education performance: A survey of the quality of local education governance in 50 Indonesian districts.

Amukowa, W., \& Ayuya, C. V. (2013). The 21st Century Educated African Person and the Loss of Africans' Educational Identity: Towards an Afro Education Model. Academic Journal of Interdisciplinary Studies, 2(1), 269-269.

Aown, N. M. (2011). A place for informal learning in teaching about religion: The story of an experienced non-Muslim teacher and her learning about Islam. Teaching and Teacher Education, 27(8), 1255-1264.

Arkoudis, S., Watty, K., Baik, C., Yu, X., Borland, H., Chang, S., Lang, I., Lang, J., \& Pearce, A. (2013). Finding common ground: Enhancing interaction between domestic and international students in higher education. Teaching in Higher Education, 18(3), 222-235.

Aslan, A. (2019a). HIDDEN CURRICULUM. Pena Indis.

Aslan, A. (2019b). MAKNA DAN HAKIKAT PENDIDIKAN BIDANG POLITIK DALAM ALQURAN. Cross-Border, 2(2), 101-109.

Aslan, A., Silvia, S., Nugroho, B. S., Ramli, M., \& Rusiadi, R. (2020). TEACHER'S LEADERSHIP TEACHING STRATEGY SUPPORTING STUDENT LEARNING DURING THE COVID-19 DISRUPTION. Nidhomul Haq : Jumal Manajemen Pendidikan Islam, 5(3), 321-333. https://doi.org/10.31538/ndh.v5i3.984

Aslan \& Wahyudin. (2020). Kurikulum dalam Tantangan Perubahan. Bookies Indonesia. https://scholar.google.com/scholar?oi=bibs\&hl=en\&cluster=17745790780728460138

Atkins, L., Francis, J., Islam, R., O’Connor, D., Patey, A., Ivers, N., Foy, R., Duncan, E. M., Colquhoun, H., \& Grimshaw, J. M. (2017). A guide to using the Theoretical Domains Framework of behaviour change to investigate implementation problems. Implementation Science, 12(1), 1-18.

Bashori, B., Prasetyo, M. A. M., \& Susanto, E. (2020). Change Management Transfromation In Islamic Education Of Indonesia. Social Work and Education, 7(1), 84-99.

Beck, U. (2014). The brave new world of work. John Wiley \& Sons.

Bunawan, W., Rangkuti, M. A., \& Yanti, J. (2019). High-Level Comprehension Skill by using Competencies PISA in Indonesia's Education System. 4th Annual International Seminar on Transformative Education and Educational Leadership (AISTEEL 2019). Atlantis Press.

Christensen, L. B., Johnson, B., Turner, L. A., \& Christensen, L. B. (2011). Research methods, design, and analysis.

Cummings, W. K. (2014). Education and equality in Japan. Princeton University Press.

de Casterlé, B. D., Gastmans, C., Bryon, E., \& Denier, Y. (2012). QUAGOL: A guide for qualitative data analysis. International Journal of Nursing Studies, 49(3), 360-371.

Dewantara, P. M. (2020). Curriculum changes in Indonesia: Teacher constraints and students of prospective teachers' readiness in the implementation of thematic learning at low grade primary school. Ilkogretim Online, 19(2).

GEBRIL, A. T. (2016). Educational assessment in Muslim countries: Values, policies, and practices. In Handbook of buman and social conditions in assessment (pp. 436-451). Routledge.

Graue, C. (2015). Qualitative data analysis. International Journal of Sales, Retailing \& Marketing, 4(9), 5-14.

Harris, A., \& Jones, M. (2020). COVID 19-school leadership in disruptive times. Taylor \& Francis. 
Hifza \& Aslan. (2020). The Model of Competitive Advantage Development in Private Islamic Education Institutions dalam "BASA 2019: Proceedings of the Third International Seminar on Recent Language, Literature, and Local Culture Studies, BASA, 20-21 September 2019, Surakarta, Central Java, Indonesia. European Alliance for Innovation.

Hifza, Juliana, Palapa, A., Maskur, \& Aslan. (2020). The Strategic Foundation for Competitive Excellent Development in Integrated Islamic Primary Schools in Indonesia. International Journal of Advanced Science and Technology, 29(12s), 1747-1753.

Huda, M., Yusuf, J. B., Azmi Jasmi, K., \& Zakaria, G. N. (2016). Understanding Comprehensive Learning Requirements in the Light of al-Zarnūjì's Ta 'lìm al-Muta 'allim. Sage Open, 6(4), 2158244016670197.

Hunter-Johnson, Y., Newton, N. G., \& Cambridge-Johnson, J. (2014). What Does Teachers' Perception Have to Do with Inclusive Education: A Bahamian Context. International Journal of Special Education, 29(1), 143-157.

Indartono, S., \& Hamidy, A. (2019). The contribution of test type and curriculum difference on the effect of the national test score at international mathematic test score: The challenge of IR 4.0 curriculum. Eurasian Journal of Educational Research, 19(82), 191-202.

Kartianom, K., \& Retnawati, H. (2018). Why are their mathematical learning achievements different? Re-analysis timss 2015 data in Indonesia, Japan and Turkey. International Journal on New Trends in Education and Their Implications, 9(2), 33-46.

Kautz, T., \& Heckman, J. J. (2014). 9. Fostering and Mea sur ing Skills: Interventions That Improve Character and Cognition. University of Chicago Press.

Kay, K., \& Greenhill, V. (2011). Twenty-first century students need 21st century skills. In Bringing schools into the 21st century (pp. 41-65). Springer.

King, R. (2010). The dynamics of international student circulation in a global context; and students, staff and academic mobility in bigher education. Taylor \& Francis.

Kolb, A. Y., \& Kolb, D. A. (2009). Experiential learning theory: A dynamic, holistic approach to management learning, education and development. The SAGE Handbook of Management Learning, Education and Development, 42, 68.

Kuraedah, S., Gunawan, F., Wekke, I. S., \& Hamuddin, B. (2018). Learning environment construction in Islamic higher education: Connecting the Puzzles of ideas. IOP Conference Series: Earth and Environmental Science, 175(1), 012107.

Kusaeri, K., Aditomo, A., Ridho, A., \& Fuad, A. (2018). Socioeconomic status, parental involvement in learning and student'mathematics achievement in Indonesian senior high school. Cakrawala Pendidikan Jurnal Ilmiah Pendidikan, 37(3), 333-344.

Lahmar, F. (2020). Islamic education: An Islamic "wisdom-based cultural environment" in a western context. Religions, 11(8), 409.

Lubis, A. H. (2018). ICT integration in 21st-century Indonesian English language teaching: Myths and realities. Jurnal Cakrawala Pendidikan, 37(1).

Lugmayr, A., Stockleben, B., Zou, Y., Anzenhofer, S., \& Jalonen, M. (2014). Applying "design thinking" in the context of media management education. Multimedia Tools and Applications, 71(1), 119-157.

Manullang, S. O., Mardani, M., Hendriarto, P., \& Aslan, A. (2021). Understanding Islam and The Impact on Indonesian Harmony and Diversity: Al-Ulum, 21(1), Article 1. https://doi.org/10.30603/au.v21i1.2188

Manullang, S. O., Risa, R., Trihudiyatmanto3, M., Masri, F. A., \& Aslan, A. (2021). Celebration of the Mawlid of Prophet Muhammad SAW: Ritual and Share Islam Value in Indonesian. Fikri: Jurnal Kajian Agama, Sosial Dan Budaya, 6(1). https://doi.org/10.25217/jf.v6i1.1324

Marienko, M., Nosenko, Y., Sukhikh, A., Tataurov, V., \& Shyshkina, M. (2020). Personalization of learning through adaptive technologies in the context of sustainable development of teachers education. ArXiv Preprint ArXiv:2006.05810. 
Mawardi, D., \& Supadi, S. (2018). Concentration on Learning Program Development in Islamic Education. AL-HAY AT: Journal Of Islamic Education, 2(2), 213-230.

McGregor, G., Mills, M., Te Riele, K., \& Hayes, D. (2015). Excluded from school: Getting a second chance at a 'meaningful'education. International Journal of Inclusive Education, 19(6), 608-625.

McMillan, J. H., \& Schumacher, S. (2010). Research in Education: Evidence-Based Inquiry, MyEducationLab Series. Pearson.

Miettinen, R. (2013). Innovation, buman capabilities, and democracy: Towards an enabling welfare state. Oxford University Press.

Mize, T. D. (2019). Best practices for estimating, interpreting, and presenting nonlinear interaction effects. Sociological Science, 6, 81-117.

Nitecki, E., \& Wasmuth, H. (2017). Global trends in early childhood practice: Working within the limitations of the global education reform movement. Global Education Review, 4(3).

Nordin, N., \& Surajudeen, A. T. (2015). Islamic theoritical model for critical thinking in teaching and learning of Islamic education. GSE E-Journal of Education, 3, 34-44.

Orchard, J., Gaydon, P., Williams, K., Bennett, P., D’Olimpio, L., Çelik, R., Shah, Q., Neusiedl, C., Suissa, J., \& Peters, M. A. (2021). Philosophy of education in a new key: A 'Covid Collective'of the Philosophy of Education Society of Great Britain (PESGB). Educational Philosophy and Theory, 53(12), 1215-1228.

Pambudi, N. A., \& Harjanto, B. (2020). Vocational education in Indonesia: History, development, opportunities, and challenges. Children and Youth Services Review, 115, 105092.

Pathak, V., Jena, B., \& Kalra, S. (2013). Qualitative research. Perspectives in Clinical Research, 4(3).

Pribudhiana, R., \& Don, B. (2021). Determining the Influence of Teacher Quality toward Teacher Readiness in Implementing Indonesian Education Policy. Eurasian Journal of Educational Research, 93, 373-390.

Pringle, R. (2010). Finding pleasure in physical education: A critical examination of the educative value of positive movement affects. Quest, 62(2), 119-134.

Purwati, N., Zubaidah, S., Corebima, A. D., \& Mahanal, S. (2018). Increasing Islamic Junior High School Students Learning Outcomes through Integration of Science Learning and Islamic Values. International Journal of Instruction, 11(4), 841-854.

Putra, P., Liriwati, F. Y., Tahrim, T., Syafrudin, S., \& Aslan, A. (2020). The Students Learning from Home Experiences during Covid-19 School Closures Policy In Indonesia. Jurnal Iqra': Kajian Ilmu Pendidikan, 5(2), 30-42. https://doi.org/10.25217/ji.v5i2.1019

Putra, P., Setianto, A. Y., Hafiz, A., Mutmainnah, \& Aslan. (2020). ETNOPEDAGOGIC STUDIES IN CHARACTER EDUCATION IN THE MILLINNEAL ERA: CASE STUDY MIN 1 SAMBAS. Al-Bidayah: Jurnal Pendidikan Dasar Islam, 12(2), 237-252. https://doi.org/10.14421/al-bidayah.v12i2.547

Rosser, A. (2018). Beyond access: Making Indonesia's education system work.

Rumahlatu, D., Huliselan, E. K., \& Takaria, J. (2016). An Analysis of the Readiness and Implementation of 2013 Curriculum in the West Part of Seram District, Maluku Province, Indonesia. International Journal of Environmental and Science Education, 11(12), 5662-5675.

Safiah, I., Degeng, I. N. S., Setyosari, P., \& Ulfa, S. (2020). Design and development of seamless learning to improving learning outcome of Islamic economic course: A case study in Indonesia. Journal of E-Learning and Knowledge Society, 16(3), 60-67.

Sahin, A. (2018). Critical issues in Islamic education studies: Rethinking Islamic and Western liberal secular values of education. Religions, 9(11), 335.

Scarino, A., Liddicoat, A., \& O’Neill, F. (2015). Engaging with diversity: A case study of the intercultural experiences of Muslim and non-Muslim students in an Australian school. International Centre for Muslim and non-Muslim Understanding, University of .... 
Scheer, S. D., Cochran, G. R., Harder, A., \& Place, N. T. (2011). Competency Modeling in Extension Education: Integrating an Academic Extension Education Model with an Extension Human Resource Management Model. Journal of Agricultural Education, 52(3), 64-74.

Setiawan, A. R. (2020). Introducing the Indonesian Education System [PhD Thesis]. Thesis Commons. DOI: https://doi. org/10.31237/osf. io/ygt5c.

Shah, S. F., \& Ghazi, S. R. (2015). Quality and Features of Education in the Muslim World. Universal Journal of Educational Research, 3(4), 243-257.

St. Amant, K. (2017). Of friction points and infrastructures: Rethinking the dynamics of offering online education in technical communication in global contexts. Technical Communication Quarterly, 26(3), 223-241.

Stevenson, N. (2010). Cultural citizenship, education and democracy: Redefining the good society. Citizenship Studies, 14(3), 275-291.

Subotnik, R. F., Olszewski-Kubilius, P., \& Worrell, F. C. (2011). Rethinking giftedness and gifted education: A proposed direction forward based on psychological science. Psychological Science in the Public Interest, 12(1), 3-54.

SUDARMO, Nugraha, M. S., MARDHIAH, R. I.liow, F. E., \& ASLAN. (2021). The Identification of Online Strategy Learning Results While Students Learn from Home During the Disruption of the COVID-19 Pandemic in Indonesia. Journal of Contemporary Issues in Business and Government, 27(2), 1950-1956. https://doi.org/10.47750/cibg.2021.27.02.205

Sudarmo, S. (2020). Human resources management and leadership for public services in the 21st century. International Journal of Business, Economics and Management, 3(1), 219-225.

Sukmayadi, V., \& Yahya, A. (2020). Indonesian Education Landscape and the 21st Century Challenges. Journal of Social Studies Education Research, 11(4), 219-234.

Suripto, S. (2020). THE ISLAMIC EDUCATION PARADIGM OF MUHAMMAD IQBAL'S PHILOSOPHY. EDUKASI: Jurnal Pendidikan Islam (e-Journal), 8(2), 150-182.

Suroso, A., Hendriarto, P., Mr, G. N. K., Pattiasina, P. J., \& Aslan, A. (2021). Challenges and opportunities towards an Islamic cultured generation: Socio-cultural analysis. Linguistics and Culture Review, 5(1), 180-194. https://doi.org/10.37028/lingcure.v5n1.1203

Takayama, K., Sriprakash, A., \& Connell, R. (2017). Toward a postcolonial comparative and international education. Comparative Education Review, 61(S1), S1-S24.

Tikly, L., \& Barrett, A. M. (2011). Social justice, capabilities and the quality of education in low income countries. International Journal of Educational Development, 31(1), 3-14.

Toi, A. (2010). An empirical study of the effects of decentralization in Indonesian junior secondary education. Educational Research for Policy and Practice, 9(2), 107-125.

Trinova, Z., Amir, D., \& Andayani, P. (2020). The Implementation Of Critical Thinking In 21ST Century Learning For Islamic Education. FITRAH: Jurnal Kajian Ilmu-Ilmu Keislaman, 6(1), 81-94.

Usman, A. H., Shaharuddin, S. A., \& Abidin, S. Z. (2017). HUMANISM IN ISLAMIC EDUCATION: INDONESIAN REFERENCES. International Journal of Asia-Pacific Studies, 13(1).

van Pinxteren, B., Emirhafizović, M., Dailidienė, I., Figurek, A., Hălbac-Cotoară-Zamfir, R., \& Mętrak, M. (2021). Education for Resilience: How a Combination of Systemic and Bottom-Up Changes in Educational Services Can Empower Dryland Communities in Africa and Central Asia. Journal of Asian and African Studies, 56(6), 1271-1285.

Wajdi, F., \& Aulia, R. N. (2019). Ma 'had'Aly and the Challenge of Modernizing Islamic Education in Indonesia. Hayula: Indonesian Journal of Multidisciplinary Islamic Studies, 3(2), 173-190.

Wang*, T. (2007). Understanding Chinese educational leaders' conceptions in an international education context. International Journal of Leadership in Education, 10(1), 71-88. 
Wiseman, A. W. (2010). The uses of evidence for educational policymaking: Global contexts and international trends. Review of Research in Education, 34(1), 1-24.

Zulfikar, T. (2010). The making of Indonesian education: An overview on empowering Indonesian teachers. Journal of Indonesian Social Sciences and Humanities, 2, 13-39. 